Article

\title{
Synthesis and Antiplasmodial Evaluation of Analogues Based on the Tricyclic Core of Thiaplakortones A-D
}

\section{Brett D. Schwartz ${ }^{1}$, Mark J. Coster ${ }^{1}$, Tina S. Skinner-Adams ${ }^{1}$, Katherine T. Andrews ${ }^{1}$, Jonathan M. White ${ }^{2}$ and Rohan A. Davis ${ }^{1, *}$}

1 Eskitis Institute for Drug Discovery, Griffith University, Nathan, Qld 4111, Australia; E-Mails: b.schwartz@griffith.edu.au (B.D.S.); m.coster@griffith.edu.au (M.J.C.); t.skinner-adams@griffith.edu.au (T.S.S.); k.andrews@griffith.edu.au (K.T.A.)

2 School of Chemistry and Bio21 Institute, University of Melbourne, Parkville, Vic 3052, Australia; E-Mail: whitejm@unimelb.edu.au

* Author to whom correspondence should be addressed; E-Mail: r.davis@griffith.edu.au; Tel.: +61-7-3735-6043; Fax: +61-7-3735-6001.

Academic Editor: Sylvia Urban

Received: 14 August 2015 / Accepted: 7 September 2015 / Published: 15 September 2015

\begin{abstract}
Six regioisomers associated with the tricyclic core of thiaplakortones A-D have been synthesized. Reaction of $1 H$-indole-4,7-dione and 1-tosyl- $1 H$-indole-4,7-dione with 2-aminoethanesulfinic acid afforded a regioisomeric series, which was subsequently deprotected and oxidized to yield the tricyclic core scaffolds present in the thiaplakortones. All compounds were fully characterized using NMR and MS data. A single crystal X-ray structure was obtained on one of the $N$-tosyl derivatives. All compounds were screened for in vitro antiplasmodial activity against chloroquine-sensitive (3D7) and multidrug-resistant (Dd2) Plasmodium falciparum parasite lines. Several analogues displayed potent inhibition of $P$. falciparum growth $\left(\mathrm{IC}_{50}<500 \mathrm{nM}\right.$ ) but only moderate selectivity for $P$. falciparum versus human neonatal foreskin fibroblast cells.
\end{abstract}

Keywords: synthesis; thiaplakortone; regioisomer; tricyclic; natural product scaffold; X-ray; crystal; Plasmodium falciparum; antiplasmodial; cytotoxicity 


\section{Introduction}

The marine natural products, thiaplakortones A-D (1-4), were first reported in 2013 as part of a Medicines for Malaria Venture sponsored research project that aimed to discover new antiplasmodial agents from nature (Figure 1) [1]. These unique thiazine-derived secondary metabolites were obtained from the organic extract from the Great Barrier Reef sponge Plakortis lita, and all were shown to inhibit the in vitro growth of Plasmodium falciparum. Thiaplakortone A (1) was the most active with in vitro IC50 values of 6.6 and $51 \mathrm{nM}$ against multidrug-resistant (Dd2) and chloroquine-sensitive (3D7) $P$. falciparum lines, respectively [1]. Due to supply issues initially curtailing in vivo malaria studies, total syntheses of thiaplakortones A and B were undertaken and the first total synthesis of $\mathbf{1}$ and $\mathbf{2}$, along with a series of mono- and di-methyl analogues (5-7) was subsequently reported and some preliminary structure-activity relationships (SAR) ascertained (Figure 1) [2]. While in vivo toxicity effects for several of the synthetic compounds indicated potential liabilities associated with this structure class, the limited number of analogues investigated made it difficult to assess their true potential as antiplasmodial leads [2]. In order to more thoroughly explore this compound class a larger analogue library based on the thiaplakortone A scaffold was recently undertaken and reported [3]. This 38-membered library consisted of a series of amide and urea analogues based on the thiaplakortone A natural product scaffold. Several analogues showed potent in vitro P. falciparum growth inhibition ( $\mathrm{IC}_{50}<500 \mathrm{nM}$ ) and good selectivity for P. falciparum versus human neonatal foreskin fibroblast (NFF) cells (selectivity index $>100$ ) [3]. Furthermore, analogues $\mathbf{8}$ and $\mathbf{9}$ displayed good metabolic stability and solubility, and when administered subcutaneously to mice plasma concentrations remained $>0.2 \mu \mathrm{M}$ for $8 \mathrm{~h}$. Analogues 8 and 9 were also well tolerated in mice after subcutaneous administration of $32 \mathrm{mg} / \mathrm{kg}$ twice daily for $4 \mathrm{~d}$. In addition, using this dosing protocol blood stage $P$. berghei parasitemia was suppressed by $52 \%$ for 8 and $26 \%$ for 9 , relative to controls [3]. In order to further investigate the thiaplakortone core, we have recently undertaken synthetic studies that resulted in the removal of the ethylamine side-chain present in thiaplakortones $A$ and $B$ in order to determine the biological implications of the $-\mathrm{CH}_{2} \mathrm{CH}_{2} \mathrm{NH}_{2}$ moiety. Herein we report the total synthesis of several side-chain truncated regioisomers associated with the tricyclic core of thiaplakortones A-D, along with their in vitro antiplasmodial activity and mammalian cell toxicity. 
<smiles>CNC(=O)CCc1c[nH]c2c1C(=O)C1=C(C2=O)S(=O)(=O)C=CN1</smiles><smiles>Cn1cc(CCN)c2c1C(=O)C1=C(C2=O)S(=O)(=O)C=CN1</smiles>

5<smiles>CNCCc1cn(C)c2c(=O)c3[nH]cc[s+]([O-])c=3c(=O)c12</smiles>

6<smiles>CNCCc1c[nH]c2c(=O)c3[nH]cc[s+]([O-])c=3c(=O)c12</smiles>

7<smiles>CC(=O)NCCc1c[nH]c2c1C(=O)C1=C(NC=CS1(=O)=O)C2=O</smiles>

8<smiles>CCCCNC(=O)NCCc1c[nH]c2c1C(=O)C1=C(NC=CS1(=O)=O)C2=O</smiles>

9

Figure 1. Chemical structures of the natural products thiaplakortones A-D (1-4) and some of the previously synthesized thiaplakortone A analogues (5-9).

\section{Results and Discussion}

\subsection{Chemistry}

The synthesis of the tricyclic core thiaplakortone isomers 11-16 commenced with the generation of 1-tosyl-1H-indole-4,7-dione (10), which was accessible via known procedures (Scheme 1) [4-6]. Condensation of $\mathbf{1 0}$ with 2-aminoethanesulfinic acid [2,7] furnished the regiomeric tricyclic systems $\mathbf{1 1}$ and 12 in an 11 to 1 ratio (Scheme 1). Separation of this mixture was not possible by silica flash chromatography however reversed-phase $\mathrm{C}_{18} \mathrm{HPLC}\left(\mathrm{MeOH}-\mathrm{H}_{2} \mathrm{O}-0.1 \% \mathrm{TFA}\right)$ enabled separation of the two regioisomers. Confirmation of the chemical structures of $\mathbf{1 1}$ and $\mathbf{1 2}$ was supported following extensive 1D and 2D NMR data analysis.

Furthermore, a crystal suitable for X-ray analysis was obtained on the major regioisomer 11 (Figure 2) confirming the NMR-assigned structure and establishing the regiochemistry of subsequent compounds in the tricyclic series. Of note, compound $\mathbf{1 1}$ crystallized with two molecules in the asymmetric unit; the second molecule displayed disorder ( $c a .13 \%)$ in the thiazine dioxide ring (see supplementary data). 


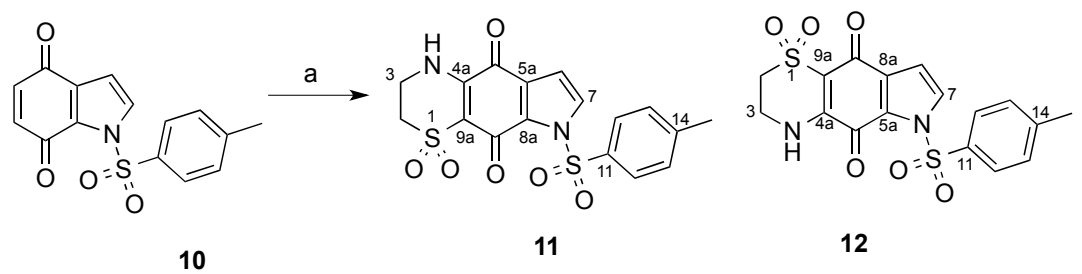

10

11

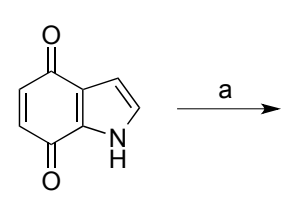

17

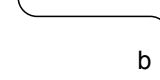

b
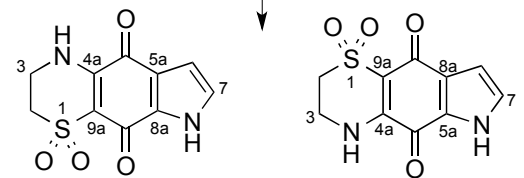

13

14

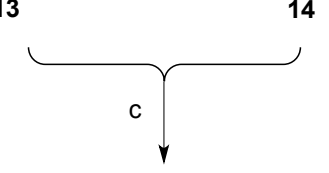

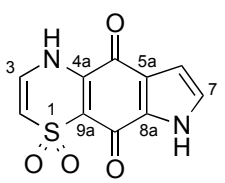

15

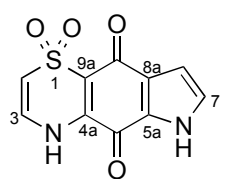

16

Scheme 1. Synthesis of compounds 11-16 in the thiaplakortone tricyclic series. (a) 2-aminoethanesulfinic acid, $\mathrm{H}_{2} \mathrm{O}, \mathrm{MeCN}$; (b) $\mathrm{NaHCO}_{3}$ (aq), $\mathrm{MeOH}$, reflux $2.5 \mathrm{~h}$; (c) $\mathrm{KOH}_{(\mathrm{aq})}, \mathrm{MeOH}, \mathrm{O}_{2}$.

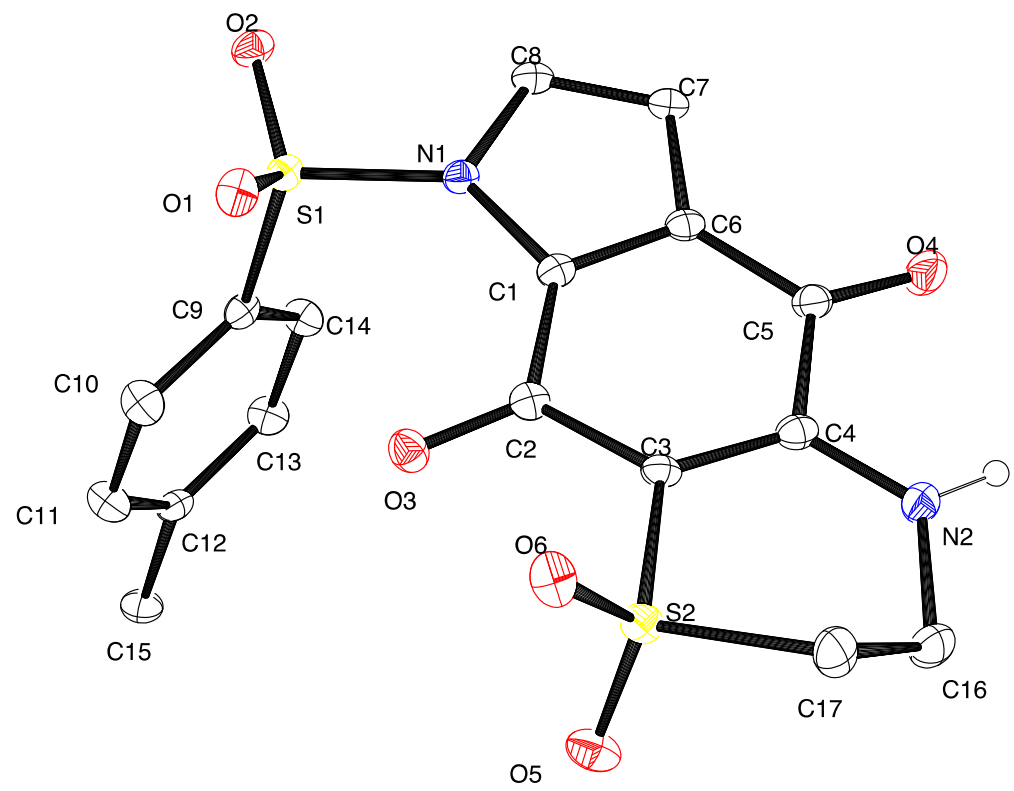

Figure 2. ORTEP diagram showing one independent molecule for compound 11; ellipsoids are at the $30 \%$ probability level.

Subjection of the mixture of tosyl derivatives $\mathbf{1 1}$ and $\mathbf{1 2}$ to mild alkaline hydrolysis afforded a sufficient quantity of only compound 13 after purification by reversed-phase HPLC (MeOH- $\left.\mathrm{H}_{2} \mathrm{O}-0.1 \% \mathrm{TFA}\right)$.

In an attempt to reverse the regioselectivity observed during the condensation of 2-aminoethanesulfinic acid with $\mathbf{1 0}$ and acquire suitable amounts of isomer 14, the parent, non-tosyl protected system, 
$1 H$-indole-4,7-dione 17 was prepared according to literature procedures $[5,8,9]$ and exposed to 2 -aminoethanesulfinic acid. Gratifyingly, in this system, the opposite regioselectivity was observed and the respective tricyclic systems $\mathbf{1 3}$ and $\mathbf{1 4}$ were formed in a 1 to 3.3 ratio following analysis of the ${ }^{1} \mathrm{H}-\mathrm{NMR}$ spectrum. Purification of this mixture by $\mathrm{C}_{18} \mathrm{HPLC}\left(\mathrm{MeOH}-\mathrm{H}_{2} \mathrm{O}-0.1 \% \mathrm{TFA}\right)$ enabled 14 to be isolated in sufficient amounts for biological testing. Oxidation of the mixture of $\mathbf{1 3}$ and $\mathbf{1 4}$ by protocols previously reported [2] afforded a mixture that was subjected to $\mathrm{C}_{18} \mathrm{HPLC}\left(\mathrm{MeOH}-\mathrm{H}_{2} \mathrm{O}-0.1 \%\right.$ TFA) and yielded the pure compounds $\mathbf{1 5}$ and $\mathbf{1 6 .}$

\subsection{Biology and Structure-Activity Relationships}

All compounds (10-17) were tested for in vitro antiplasmodial activity against chloroquine-sensitive (3D7) and multidrug-resistant (Dd2) P. falciparum parasite lines, and for mammalian toxicity using human neonatal foreskin fibroblast (NFF) cells. The simple indolequinones, $\mathbf{1 0}$ and $\mathbf{1 7}$, were essentially inactive (Table 1), highlighting the importance of the 1,1-dioxo-thiazine subunit for antiplasmodial activity. The original thiaplakortone report [1] showed that unsaturation of the thiazine ring conferred enhanced antiplasmodial activity. This trend was also observed in the side-chain truncated compounds, with the unsaturated compounds, $\mathbf{1 5}$ and $\mathbf{1 6}$ displaying greater potency than their saturated counterparts, 13 and 14, respectively. Specifically, exchanging the saturated system of $\mathbf{1 3}$ and $\mathbf{1 4}$ with the unsaturated motif present in 15 and 16 increased 3D7 activity by 23.9- and 27.3-fold, respectively; a similar SAR trend was also observed for this series towards the Dd2 line.

Table 1. Biological Data for Compounds 10-17.

\begin{tabular}{ccccc}
\hline \multicolumn{5}{c}{ Mean IC $_{\mathbf{5 0}} \pm \mathbf{S D}(\mathbf{n M})$} \\
\hline Compound & $3 \mathrm{D}^{a}$ & $\mathrm{Dd} 2^{b}$ & $\mathrm{NFF}^{c}$ & $\mathrm{SI}^{d}$ \\
$\mathbf{1 0}$ & $18,200 \pm 2600$ & $11,100 \pm 4100$ & $7600 \pm 1200$ & $0.4-0.7$ \\
$\mathbf{1 1}$ & $546 \pm 119$ & $509 \pm 309$ & $1400 \pm 700$ & $2.6-2.8$ \\
$\mathbf{1 2}$ & $834 \pm 89$ & $607 \pm 158$ & $19,000 \pm 11,000$ & $22.8-31.3$ \\
$\mathbf{1 3}$ & $7500 \pm 900$ & $3800 \pm 400$ & $39,000 \pm 4200$ & $5.2-10.3$ \\
$\mathbf{1 4}$ & $6900 \pm 700$ & $3700 \pm 500$ & $69,600 \pm 5900$ & $10.1-18.8$ \\
$\mathbf{1 5}$ & $313 \pm 84$ & $129 \pm 3.9$ & $2800 \pm 400$ & $8.9-21.7$ \\
$\mathbf{1 6}$ & $252 \pm 35$ & $127 \pm 8.6$ & $4600 \pm 800$ & $18.2-36.2$ \\
$\mathbf{1 7}$ & $13,500 \pm 6700$ & $11,500 \pm 6500$ & $4700 \pm 100$ & $0.3-0.4$ \\
$\mathbf{C Q} \mathbf{Q}^{e}$ & $7.8 \pm 2.7$ & $45 \pm 10$ & $36,500 \pm 6000$ & $811.1-4679.5$ \\
\hline
\end{tabular}

${ }^{a} 3 \mathrm{D} 7=$ P. falciparum chloroquine-sensitive line; ${ }^{b} \mathrm{Dd} 2=P$. falciparum multidrug-resistant line; ${ }^{c} \mathrm{NFF}=$ neonatal foreskin fibroblast cells; ${ }^{d} \mathrm{SI}=$ selectivity index $=\mathrm{NFF}$ cell-line $\mathrm{IC}_{50} / P$. falciparum $\mathrm{IC}_{50} ;{ }^{e} \mathrm{CQ}=$ chloroquine (positive control).

The regiochemistry of the thiazine moiety in the original thiaplakortone report was shown to have minimal influence on the overall antiplasmodial activity and selectivity [1]. Reversal of the thiazine orientation in thiaplakortones C (3) and D (4) only showed an antiplasmodial activity increase of 1.1-fold towards both the 3D7 and Dd2 lines. In a similar manner to the earlier report, the current studies showed minimal differences in parasite potency between the side-chain truncated regioisomeric pairs, 11 and 12, 13 and 14, and 15 and 16. However, when comparing NFF toxicity of the regioisomers (11 $v s .12 ; 13$ vs. $14 ; 15$ vs. 16) a clear trend was observed, with the thiazine regiochemistry present in $\mathbf{1 2}$, 
14 and 16 conveying reduced cytotoxicity ranging from 1.6- to 13.6-fold. Furthermore, the reduction in toxicity improved the selectivity indices for analogues 12, 14 and 16.

Biological data for compounds $\mathbf{1 1}$ and $\mathbf{1 2}$ identified that $N$-tosylation of the pyrrole moiety is well tolerated and improves antiparasitic activity, even in the absence of thiazine unsaturation. It is interesting to note that, consistent with the thiaplakortone natural products [1], the most active side-chain truncated analogues, $\mathbf{1 5}$ and 16, are more potent against the drug-resistant line (Dd2) than the chloroquine-sensitive line (3D7). While it is clear that the ethylamine side-chain present in thiaplakortones A and B translates to more potent and selective antiplasmodial agents, the current study shows that the tricyclic core motif present in 11-16 represents a minimum antiplasmodial pharmacophore for the thiaplakortone chemotype.

In order to assess the drug-like properties of compounds 10-17, in silico physicochemical parameters (Table 2) were calculated using ChemAxon MarvinSketch software (with calculator plugins) (http://www.chemaxon.com) and the data compared to Lipinski's drug-like "Rule of Five" [10]. All compounds complied with Lipinski's rules $(\log \mathrm{P}<5, \mathrm{HBA}<10, \mathrm{HBD}<5, \mathrm{MW}<500)$. In addition, all compounds had relatively $\operatorname{low} \log \mathrm{D}_{7.4}$ values (except compound 10), and had appropriate polar surface area (PSA) values for membrane penetration.

Table 2. In silico physicochemical parameters for compounds $10-17^{a}$.

\begin{tabular}{ccccccc}
\hline Compound & MW & LogP & HBA & HBD & PSA $\left(\mathbf{\AA}^{2}\right)$ & LogD $_{7.4}$ \\
\hline $\mathbf{1 0}$ & 301 & 1.5 & 4 & 0 & 82 & 1.9 \\
$\mathbf{1 1}$ & 406 & -1.6 & 7 & 1 & 136 & -0.2 \\
$\mathbf{1 2}$ & 406 & -1.6 & 7 & 1 & 136 & -0.2 \\
$\mathbf{1 3}$ & 252 & -3.3 & 5 & 2 & 104 & -1.6 \\
$\mathbf{1 4}$ & 252 & -3.3 & 5 & 2 & 104 & -1.6 \\
$\mathbf{1 5}$ & 250 & -2.9 & 5 & 2 & 104 & -1.5 \\
$\mathbf{1 6}$ & 250 & -2.9 & 5 & 2 & 104 & -1.5 \\
$\mathbf{1 7}$ & 147 & -0.2 & 2 & 1 & 50 & 0.5 \\
\hline
\end{tabular}

a In silico calculations performed using ChemAxon MarvinSketch software (with calculator plugins). $\mathrm{MW}=$ molecular weight $(\mathrm{Da}) ; \mathrm{HBA}=\mathrm{H}$-bond acceptors; HBD = H-bond donors; PSA = polar surface area.

\section{Experimental Section}

\subsection{General}

Melting points were recorded on a capillary melting point apparatus and are uncorrected. Unless otherwise specified, ${ }^{1} \mathrm{H}$ and ${ }^{13} \mathrm{C}$-NMR spectra were recorded at $30{ }^{\circ} \mathrm{C}$ in DMSO- $d_{6}$ on a Varian INOVA 500 or 600 NMR spectrometer. The ${ }^{1} \mathrm{H}$ - and ${ }^{13} \mathrm{C}$-NMR chemical shifts were referenced to the solvent peak for DMSO- $d_{6}$ at $\delta_{\mathrm{H}} 2.50$ and $\delta_{\mathrm{C}} 39.5$. LRESIMS was obtained from LC-MS data generated using a Waters Alliance 2790 HPLC equipped with a Waters 996 photodiode array detector and an Alltech evaporative light scattering detector that was attached to a Water ZQ mass spectrometer. HRESIMS were recorded on a Bruker (Billerica, MA, USA) MicrOTof-Q spectrometer (Dionex UltiMate 3000 micro LC system, ESI mode). Analytical thin layer chromatography (TLC) was performed on aluminum-backed $0.2 \mathrm{~mm}$ thick silica gel $60 \mathrm{~F}_{254}$ plates as supplied by Merck (Frankfurt, Germany). Eluted plates were visualized using a $254 \mathrm{~nm}$ UV lamp and/or by treatment with a suitable dip followed by heating. These dips included phosphomolybdic acid:Ce( $\left.\mathrm{SO}_{4}\right)_{2}: \mathrm{H}_{2} \mathrm{SO}_{4}$ (conc.): $\mathrm{H}_{2} \mathrm{O}$ (37.5 g:7.5 g: 
$37.5 \mathrm{~g}: 720 \mathrm{~mL}$ ) or $\mathrm{KMnO}_{4}: \mathrm{K}_{2} \mathrm{CO}_{3}: 5 \% \mathrm{NaOH}$ aqueous solution: $\mathrm{H}_{2} \mathrm{O}$ (3 g:20 g:5 mL:300 mL). Flash chromatographic separations were carried out following protocols defined by Still et al., [11] with silica gel 60 (40-63 mm, supplied by GRACE, Baulkham Hills, NSW, Australia) or amino bonded silica gel (Davisil $^{\circledR}$ ) as the stationary phase and using the AR- or HPLC-grade solvents indicated. Semi-preparative HPLC work was performed using a Waters 600 pump and 966 PDA detector, a Gilson 715 liquid handler and a $\mathrm{C}_{18}$-bonded silica Betasil $5 \mu \mathrm{m} 143 \AA$ column $(21.2 \mathrm{~mm} \times 150 \mathrm{~mm})$. Alltech sample preparative $\mathrm{C}_{18}$-bonded silica $(35-75 \mu \mathrm{m}, 150 \AA)$ and an Alltech stainless steel guard cartridge $(10 \mathrm{~mm} \times 30 \mathrm{~mm})$ were used for pre-adsorption and HPLC work. A Phenomenex $\mathrm{C}_{18}$-bonded silica Luna $3 \mu \mathrm{m} 100 \AA$ $(4.6 \mathrm{~mm} \times 50 \mathrm{~mm})$ column was used for LC-MS studies. All compounds were analyzed for purity using LC-MS and shown to be $>95 \%$ pure, unless otherwise stated. Starting materials and reagents were available from the Sigma-Aldrich (St. Louis, MO, USA), Merck (Frankfurt, Germany), AK Scientific Inc. (Union City, CA, USA), Matrix Scientific Chemical (Columbia, SC, USA) and were used as supplied. $\mathrm{MeOH}$ and $\mathrm{CH}_{2} \mathrm{Cl}_{2}$ were dried using a glass contour solvent purification system that is based upon a technology originally described by Grubbs et al. [12]. Where necessary, reactions were performed under a nitrogen atmosphere and glassware was heated in an oven at $140{ }^{\circ} \mathrm{C}$ then dried under vacuum prior to use. Compounds for biological studies were placed under high vacuum $(0.05 \mathrm{mmHg})$ for several hours before testing to remove trace, residual solvents.

\subsection{Synthesis of N-Tosyl Regioisomers 11 and 12}

A solution of $N$-tosyl-1H-indole-4,7-dione $(500 \mathrm{mg}, 1.66 \mathrm{mmol})$ in $\mathrm{MeCN}(80 \mathrm{~mL})$ was treated with a solution of 2-aminoethanesulfinic acid (236 mg, $2.16 \mathrm{mmol})$ in $\mathrm{H}_{2} \mathrm{O}(50 \mathrm{~mL})$ in one portion. The mixture was stirred for $20 \mathrm{~h}$ open to the atmosphere and then $\mathrm{H}_{2} \mathrm{O}$ was removed by rotary evaporation and the resulting solid collected by vacuum filtration. The crystals were washed with $\mathrm{H}_{2} \mathrm{O}(20 \mathrm{~mL})$ then dried to afford a crude $\sim 1: 11$ mixture of regioisomers 12 and 11, respectively. This material (236 $\mathrm{mg}$ ) was pre-adsorbed to $\mathrm{C}_{18}$-bonded silica $(1 \mathrm{~g})$ overnight, then packed into a guard cartridge that was subsequently attached to a $\mathrm{C}_{18}$-bonded silica semi-preparative HPLC column. Isocratic HPLC conditions of $90 \% \mathrm{H}_{2} \mathrm{O}(0.1 \% \mathrm{TFA}) / 10 \% \mathrm{MeOH}(0.1 \% \mathrm{TFA})$ were employed for the first $10 \mathrm{~min}$, then a linear gradient to $\mathrm{MeOH}(0.1 \%$ TFA) was run over $40 \mathrm{~min}$, followed by isocratic conditions of $\mathrm{MeOH}(0.1 \%$ TFA) for a further $10 \mathrm{~min}$, all at a flow rate of $9 \mathrm{~mL} / \mathrm{min}$. Sixty fractions $(60 \times 1 \mathrm{~min})$ were collected by time from the start of the HPLC run. All UV active fractions were analyzed by ${ }^{1} \mathrm{H}-\mathrm{NMR}$ spectroscopy and MS, and identical fractions were combined. This afforded $12\left(7.6 \mathrm{mg}, 1 \%,{ }^{\mathrm{t}} \mathrm{R}=37.0-38.0 \mathrm{~min}\right)$ and $11\left(69 \mathrm{mg}, 10 \%,{ }^{\mathrm{t}} \mathrm{R}=53.0-60.0 \mathrm{~min}\right)$. X-ray quality crystals of 11 were obtained through slow evaporation using a $\mathrm{H}_{2} \mathrm{O} / \mathrm{MeOH}(1: 9)$ mix.

Compound 11: Dull orange crystals $\left(\mathrm{H}_{2} \mathrm{O} / \mathrm{MeOH}\right) ; \mathrm{mp}>300{ }^{\circ} \mathrm{C} ;{ }^{1} \mathrm{H}-\mathrm{NMR}\left(600 \mathrm{MHz}, \mathrm{DMSO}-d_{6}\right)$ $\delta_{\mathrm{H}} 2.42$ (3H, s, H-15), 3.27-3.29 (2H, m, H-2), 3.76-3.78 (2H, m, H-3), 6.83 (1H, d, J= $\left.3.4 \mathrm{~Hz}, \mathrm{H}-6\right)$, $7.50(2 \mathrm{H}, \mathrm{d}, J=8.2 \mathrm{~Hz}, \mathrm{H}-13), 7.90(2 \mathrm{H}, \mathrm{d}, J=3.4 \mathrm{~Hz}, \mathrm{H}-7), 8.01(2 \mathrm{H}, \mathrm{d}, J=8.2 \mathrm{~Hz}, \mathrm{H}-12), 9.01$ $\left(1 \mathrm{H}\right.$, br s, H-4); ${ }^{13} \mathrm{C}-\mathrm{NMR}\left(150 \mathrm{MHz}, \mathrm{DMSO}-d_{6}\right) \delta_{\mathrm{C}} 21.2$ (C-15), 39.3 (C-3), 48.2 (C-2), 107.5 (C-6), 108.2 (C-9a), 126.7 (C-5a), 128.6 (2C, C-12), 129.3 (C-7), 129.8 (2C, C-13), 130.8 (C-8a), 133.5 (C-11), 146.2 (C-14), 146.6 (C-4a), 167.1 (C-9), 175.1 (C-5); (+)-LRESIMS m/z (rel. int.) 407 (100) $[\mathrm{M}+\mathrm{H}]^{+}$; (-)-LRESIMS $m / z$ (rel. int.) $405(100)[\mathrm{M}-\mathrm{H}]^{-}$; (+)-HRESIMS $m / z 429.0200[\mathrm{M}+\mathrm{Na}]^{+}$ (calcd for $\mathrm{C}_{17} \mathrm{H}_{14} \mathrm{~N}_{2} \mathrm{NaO}_{6} \mathrm{~S}_{2}, 429.0185$ ). 
Compound 12: Bright orange amorphous solid; ${ }^{1} \mathrm{H}-\mathrm{NMR}(600 \mathrm{MHz}, \mathrm{DMSO}-d 6) \delta_{\mathrm{H}} 2.41(3 \mathrm{H}, \mathrm{s}, \mathrm{H}-15)$, 3.26-3.28 (2H, m, H-2), 3.75-3.77 (2H, m, H-3), 6.81 (1H, d, J=3.2 Hz, H-8), 7.48 (2H, d, J = 8.4 Hz, $\mathrm{H}-13), 7.98$ (2H, d, $J=8.4 \mathrm{~Hz}, \mathrm{H}-12), 8.12(2 \mathrm{H}, \mathrm{d}, J=3.2 \mathrm{~Hz}, \mathrm{H}-7), 9.13$ (1H, br s, H-4); ${ }^{13} \mathrm{C}-\mathrm{NMR}$ (150 MHz, DMSO-d6) $\delta_{\mathrm{c}} 21.1$ (C-15), 39.2 (C-3), 47.9 (C-2), 108.0 (C-9a), 108.8 (C-8), 125.9 (C-8a), 128.3 (2C, C-12), 130.0 (2C, C-13), 133.1 (C-11), 133.2 (C-7), 133.3 (C-5a), 146.4 (C-14), 147.4 (C-4a), 166.3 (C-5), 172.9 (C-9); (-)-LRESIMS m/z (rel. int.) 405 (100) [M - H] $]^{-}$; (+)-LRESIMS $m / z$ (rel. int.) $407(100)[\mathrm{M}+\mathrm{H}]^{+}$; (+)-HRESIMS $m / z 429.0167[\mathrm{M}+\mathrm{Na}]^{+}$(calcd for $\mathrm{C}_{17} \mathrm{H}_{14} \mathrm{~N}_{2} \mathrm{NaO}_{6} \mathrm{~S}_{2}$, 429.0185).

\subsection{Deprotection of the N-Tosyl Regioisomer Mixture to Yield 13}

A 1:11 mixture of 12 and $11(140 \mathrm{mg}, 0.35 \mathrm{mmol})$ in a saturated solution of $\mathrm{NaHCO}_{3}(5 \mathrm{~mL})$ and $\mathrm{MeOH}(50 \mathrm{~mL})$ was heated to reflux for $2.5 \mathrm{~h}$. The mixture was acidified with $\mathrm{HCl}(32 \%$ aqueous) to pH 6 then concentrated and subjected to flash chromatography (silica, 1:10 v/v $\mathrm{MeOH} / \mathrm{CH}_{2} \mathrm{Cl}_{2}$ elution) to afford a 1:26 mixture of compounds 14 and 13 (59 mg, 68\%). This material (59 mg) was pre-adsorbed to $\mathrm{C}_{18}$-bonded silica ( $1 \mathrm{~g}$ ) overnight, then packed into a guard cartridge that was attached to a $\mathrm{C}_{18}$-bonded silica semi-preparative HPLC column. Application of the same reversed-phase HPLC purification method described above (Section 3.2) afforded $13\left(15 \mathrm{mg}, 11 \%,{ }^{t} \mathrm{R}=23.0-24.0 \mathrm{~min}\right.$ ) as an orange powder.

Compound 13: Orange amorphous solid; ${ }^{1} \mathrm{H}-\mathrm{NMR}\left(500 \mathrm{MHz}, \mathrm{DMSO}-d_{6}\right) \delta_{\mathrm{H}} 3.31-3.33$ (2H, m, H-2), 3.81-3.84 (2H, m, H-3), $6.57(1 \mathrm{H}, \mathrm{d}, J=2.8 \mathrm{~Hz}, \mathrm{H}-6), 7.13(1 \mathrm{H}, \mathrm{d}, J=2.8 \mathrm{~Hz}, \mathrm{H}-7), 9.05$ (1H, brs, H-4), 12.76 (1H, brs, H-8); ${ }^{13} \mathrm{C}-\mathrm{NMR}\left(125 \mathrm{MHz}, \mathrm{DMSO}-d_{6}\right) \delta_{\mathrm{C}} 39.4$ (C-3), 48.2 (C-2), 107.5 (C-6), 120.7 (C-5a), 125.4 (C-7), 132.9 (C-8a), 148.2 (C-4a), 169.8 (C-9), 174.1 (C-5); (+)-LRESIMS m/z (rel. int.) $253(100)[\mathrm{M}+\mathrm{H}]^{+}$; (-)-LRESIMS $m / z$ (rel. int.) $251(100)[\mathrm{M}-\mathrm{H}]^{-}$; (+)-HRESIMS $m / z 275.0104$ $[\mathrm{M}+\mathrm{Na}]^{+}$(calcd for $\left.\mathrm{C}_{10} \mathrm{H}_{8} \mathrm{~N}_{2} \mathrm{NaO}_{4} \mathrm{~S}, 275.0097\right)$.

\subsection{Synthesis of Regioisomers 13 and 14}

A solution of $1 H$-indole-4,7-dione $\mathbf{( 1 0 , 5 0 4 ~ m g , ~} 3.4 \mathrm{mmol})$ in $\mathrm{MeCN}(160 \mathrm{~mL})$ was treated with a solution of 2-aminoethanesulfinic acid (482 mg, $4.42 \mathrm{mmol})$ in $\mathrm{H}_{2} \mathrm{O}(50 \mathrm{~mL})$ in one portion and the mixture stirred for $20 \mathrm{~h}$ under an atmosphere of $\mathrm{O}_{2}$. The $\mathrm{MeCN}$ and $\mathrm{H}_{2} \mathrm{O}$ were removed by rotary evaporation to afford an orange solid, which was purified by flash chromatography (silica, 1:5 v/v $\mathrm{MeOH} / \mathrm{CH}_{2} \mathrm{Cl}_{2}$ elution) to afford a 3.3:1 mixture of regioisomers 14 and $\mathbf{1 3}$, respectively (307 $\mathrm{mg}, 36 \%$ ). A portion of this material $(40 \mathrm{mg})$ was pre-adsorbed to $\mathrm{C}_{18}$-bonded silica $(1 \mathrm{~g})$ overnight, then packed into a guard cartridge that was attached to a $\mathrm{C}_{18}$-bonded silica semi-preparative HPLC column. Isocratic HPLC conditions of $95 \% \mathrm{H}_{2} \mathrm{O}(0.1 \% \mathrm{TFA}) / 5 \% \mathrm{MeOH}(0.1 \% \mathrm{TFA})$ were employed for the first $10 \mathrm{~min}$, then a linear gradient to $50 \% \mathrm{H}_{2} \mathrm{O}(0.1 \% \mathrm{TFA}) / 50 \% \mathrm{MeOH}(0.1 \% \mathrm{TFA})$ was run over $40 \mathrm{~min}$, followed by a linear gradient to $\mathrm{MeOH}(0.1 \%$ TFA $)$ in $1 \mathrm{~min}$, then isocratic conditions of $\mathrm{MeOH}(0.1 \% \mathrm{TFA})$ for a further $9 \mathrm{~min}$, all at a flow rate of $9 \mathrm{~mL} / \mathrm{min}$. Sixty fractions $(60 \times 1 \mathrm{~min})$ were collected by time from the start of the HPLC run. All UV active fractions were analyzed by ${ }^{1} \mathrm{H}-\mathrm{NMR}$ spectroscopy and MS, and identical fractions were combined. This yielded $14\left(5.0 \mathrm{mg}, 1 \%,{ }^{\mathrm{t}} \mathrm{R}=25.0-27.0 \mathrm{~min}\right)$ as a bright orange powder.

Compound 14: Bright orange amorphous solid; ${ }^{1} \mathrm{H}-\mathrm{NMR}\left(500 \mathrm{MHz}, \mathrm{DMSO}-d_{6}\right) \delta_{\mathrm{H}} 3.28-3.33(2 \mathrm{H}$, m, H-2), 3.79-3.82 (2H, m, H-3), 6.53 (1H, d, J=2.5 Hz, H-8), 7.40 (1H, d, J=2.5 Hz, H-7), 8.89 (1H, 
br s, H-4), 12.81 (1H, br s, H-6); ${ }^{13} \mathrm{C}-\mathrm{NMR}\left(125 \mathrm{MHz}, \mathrm{DMSO}-d_{6}\right) \delta \mathrm{c} 39.3$ (C-3), 48.4 (C-2), 108.4 (2C, C-9a, C-8), 127.2 (C-8a), 128.2 (C-5a), 130.1 (C-7), 147.5 (C-4a), 167.9 (C-5), 174.7 (C-9); (+)-LRESIMS $m / z$ (rel. int.) $253(100)[\mathrm{M}+\mathrm{H}]^{+}$; (-)-LRESIMS $m / z$ (rel. int.) 251 (100) $[\mathrm{M}-\mathrm{H}]^{-}$; $(+)$-HRESIMS $m / z 275.0087[\mathrm{M}+\mathrm{Na}]^{+}$(calcd for $\mathrm{C}_{10} \mathrm{H}_{8} \mathrm{~N}_{2} \mathrm{NaO}_{4} \mathrm{~S}, 275.0097$ ).

\subsection{Synthesis of Regioisomers 15 and 16}

A 3.3:1 regioisomeric mixture of $\mathbf{1 4}$ and $\mathbf{1 3}(90 \mathrm{mg}, 0.36 \mathrm{mmol})$ from the synthesis described above (Section 3.4) in a solution of $\mathrm{MeOH}(10 \mathrm{~mL})$ was treated with an aqueous $\mathrm{KOH}$ solution $(6 \mathrm{~mL}, 12 \mathrm{M})$. The magnetically stirred reaction mixture was purged with $\mathrm{O}_{2}$, and maintained at $60{ }^{\circ} \mathrm{C}$ under a balloon of $\mathrm{O}_{2}$ for $4 \mathrm{~h}$. The reaction mixture was cooled to $0^{\circ} \mathrm{C}$, carefully neutralized by the addition of an aqueous solution of $\mathrm{HCl}(1 \mathrm{M})$ and then the mixture was concentrated in vacuo to afford a residue that was subjected to flash chromatography through a small plug of silica $\left(1: 10 v / v \mathrm{MeOH} / \mathrm{CH}_{2} \mathrm{Cl}_{2}\right.$ elution) and after concentration of the eluent in vacuo, the residue $\left(40 \mathrm{mg}\right.$ ) was pre-adsorbed to $\mathrm{C}_{18}$-bonded silica $(1 \mathrm{~g})$ overnight, then packed into a guard cartridge that was attached to a $\mathrm{C}_{18}$-bonded silica semi-preparative HPLC column. Application of same reversed-phase HPLC purification method described above (section 3.4) resulted in the purification of compounds $16\left(15 \mathrm{mg}, 17 \%,{ }^{\mathrm{t}} \mathrm{R}=28.0-30.0 \mathrm{~min}\right)$ and $15(5 \mathrm{mg}, 6 \%$, ${ }^{\mathrm{t}} \mathrm{R}=32.0-34.0 \mathrm{~min}$ ) as yellow and orange powders, respectively.

Compound 15: Orange amorphous solid; ${ }^{1} \mathrm{H}-\mathrm{NMR}\left(500 \mathrm{MHz}, \mathrm{DMSO}-d_{6}\right) \delta_{\mathrm{H}} 6.49(1 \mathrm{H}, \mathrm{d}, J=8.8 \mathrm{~Hz}$, H-2), $6.66(1 \mathrm{H}, \mathrm{d}, J=2.8 \mathrm{~Hz}, \mathrm{H}-6), 7.07$ (1H, d, $J=8.8 \mathrm{~Hz}, \mathrm{H}-3), 7.27$ (1H, d, $J=2.8 \mathrm{~Hz}, \mathrm{H}-7), 11.07$ (1H, br s, H-4), 12.99 (1H, br s, H-8); ${ }^{13} \mathrm{C}-\mathrm{NMR}$ (125 MHz, DMSO-d6) $\delta \mathrm{c} 108.0$ (C-6), 111.7 (C-2), 113.4 (C-9a), 121.8 (C-5a), 126.8 (C-7), 130.2 (C-3), 131.3 (C-8a), 140.5 (C-4a), 172.2 (C-9), 174.1 (C-5); (+)-LRESIMS $m / z$ (rel. int.) $251(100)[\mathrm{M}+\mathrm{H}]^{+}$; (-)-LRESIMS $m / z$ (rel. int.) 249 (100) $[\mathrm{M}-\mathrm{H}]^{-} ;(+)$-HRESIMS $m / z 272.9939[\mathrm{M}+\mathrm{Na}]^{+}$(calcd for $\mathrm{C}_{10} \mathrm{H}_{6} \mathrm{~N}_{2} \mathrm{NaO}_{4} \mathrm{~S}, 272.9940$ ).

Compound 16: Yellow amorphous solid; ${ }^{1} \mathrm{H}$ NMR $\left(500 \mathrm{MHz}, \mathrm{DMSO}-d_{6}\right) \delta_{\mathrm{H}} 6.42(1 \mathrm{H}, \mathrm{d}, J=8.8 \mathrm{~Hz}$, H-2), $6.60(1 \mathrm{H}, \mathrm{d}, J=2.6 \mathrm{~Hz}, \mathrm{H}-8), 7.04(1 \mathrm{H}, \mathrm{d}, J=8.8 \mathrm{~Hz}, \mathrm{H}-3), 7.43$ (1H, d, $J=2.6 \mathrm{~Hz}, \mathrm{H}-7), \mathrm{H}-4$ and H-6 not observed; ${ }^{13} \mathrm{C}-\mathrm{NMR}\left(125 \mathrm{MHz}\right.$, DMSO- $\left.d_{6}\right) \delta \mathrm{c} 108.5$ (C-8), $111.6(\mathrm{C}-2), 113.9(\mathrm{C}-9 \mathrm{a}), 126.9$ (C-8a), 127.6 (C-5a), 129.8 (C-7), 130.1 (C-3), 140.2 (C-4a), 167.9 (C-5), 177.3 (C-9); (+)-LRESIMS $m / z$ (rel. int.) $251(100)[\mathrm{M}+\mathrm{H}]^{+}$; (-)-LRESIMS $m / z$ (rel. int.) 249 (100) $[\mathrm{M}-\mathrm{H}]^{-}$; (+)-HRESIMS $m / z 272.9933[\mathrm{M}+\mathrm{Na}]^{+}$(calcd for $\mathrm{C}_{10} \mathrm{H}_{6} \mathrm{~N}_{2} \mathrm{NaO}_{4} \mathrm{~S}, 272.9940$ ).

\subsection{X-ray Crystallography Studies on Compound 11}

Intensity data were collected with an Oxford Diffraction SuperNova CCD diffractometer using $\mathrm{Cu}-\mathrm{K} \alpha$ radiation, the temperature during data collection was maintained at 100.0(1) using an Oxford Cryosystems cooling device. The structure was solved by direct methods and difference Fourier Synthesis [13]. Hydrogen atoms bound to the carbon atom were placed at their idealized positions using appropriate HFIX instructions in SHELXL, and included in subsequent refinement cycles. Hydrogen atoms attached to nitrogen were located from difference Fourier maps and refined freely with isotropic displacement parameters. Thermal ellipsoid plots were generated using the program ORTEP-3 [14] integrated within the WINGX suite of programs [15]. Full details of the data collection and refinement and tables of atomic coordinates, bond lengths and angles, and torsion angles have been deposited with 
the Cambridge Crystallographic Data Centre (CCDC 1416796). Copies can be obtained free of charge on application at the following address: http://www.ccdc.cam.ac.uk.

Crystal data for compound 11: $\mathrm{C}_{17} \mathrm{H}_{14} \mathrm{~N}_{2} \mathrm{O}_{6} \mathrm{~S}_{2}, M=406.42, T=100.0(2) \mathrm{K}, \lambda=1.5418 \AA$, Triclinic, space group $P_{21} / c, a=11.6802(7), b=28.0975(14), c=10.3047(6) \AA, \beta=91.539(5)^{\circ} \mathrm{V}=3380.6(3) \AA^{3}$, $Z=8, Z^{\prime}=2, D_{c}=1.597 \mathrm{Mg} \cdot \mathrm{M}^{-3}, \mu=3.230 \mathrm{~mm}^{-1}, F(000)=1680$, crystal size $0.49 \mathrm{~mm} \times 0.38 \mathrm{~mm} \times$ $0.31 \mathrm{~mm} . \theta_{\max }=67.6^{\circ}, 10,831$ reflections measured, 5907 independent reflections $\left(R_{\text {int }}=0.051\right)$ the final $R=0.0559[\mathrm{I}>2 \sigma(\mathrm{I}), 5134$ data $]$ and $w \mathrm{R}\left(\mathrm{F}^{2}\right)=0.1577$ (all data) GOOF $=1.027$.

\subsection{P. Falciparum Growth Inhibition Assay}

$P$. falciparum growth inhibition assays were carried out using an isotopic microtest, as previously described [16]. Briefly, in vitro cultured $P$. falciparum infected erythrocytes (1.0\% parasitemia and $1.0 \%$ hematocrit) were seeded into triplicate wells of 96 well tissue culture plates containing vehicle control (DMSO), positive control [chloroquine (Sigma-Aldrich, St. Louis, MO, USA), catalogue \#C6628, >98\%] or test compounds and incubated under standard $P$. falciparum culture conditions with $0.5 \mu \mathrm{Ci}$ $\left[{ }^{3} \mathrm{H}\right]$-hypoxanthine. The final concentration of DMSO vehicle was $<0.5 \%$ in all assay wells (non-toxic). After $48 \mathrm{~h}$ cells were harvested onto 1450 MicroBeta filter mats (PerkinElmer, Waltham, Massachusetts, USA) and $\left[{ }^{3} \mathrm{H}\right]$ incorporation determined using a 1450 MicroBeta liquid scintillation counter. Percentage inhibition of growth compared to matched DMSO controls was determined and $\mathrm{IC}_{50}$ values were calculated using linear interpolation of inhibition curves [17]. The mean $\mathrm{IC}_{50}$ or $\%$ inhibition $( \pm \mathrm{SD})$ was calculated for three independent experiments, each carried out in triplicate.

\section{Conclusions}

In summary, six analogues associated with the tricyclic core of thiaplakortones were synthesized from readily accessible and known $1 H$-indole-4,7-dione derivatives, and isolated in low to moderate yields. Regiochemistry was moderated by substitution of the indole nitrogen. All compounds were tested for in vitro antiplasmodial activity towards two $P$. falciparum parasite lines (3D7 and Dd2). Compound 16 showed the best antiparasitic activity with $\mathrm{IC}_{50}$ values of 252 and $127 \mathrm{nM}$ towards 3D7 and Dd2 lines, respectively. The moderate toxicity ( $\mathrm{IC}_{50} 4600 \mathrm{nM}$ ) of compound $\mathbf{1 6}$ towards NFF cells equates to a selectivity index of 18.2-36.2. These studies have identified that while the ethylamine side-chain present in the marine natural products, thiaplakortones $\mathrm{A}$ and $\mathrm{B}$, translates to more potent and selective antiplasmodial compounds, this functionality is by no means essential for activity. Furthermore, the truncated thiaplakortone molecules (11-16) synthesized during this work has allowed delineation of a minimum antiplasmodial pharmacophore for the thiaplakortone chemotype.

\section{Acknowledgments}

We thank the National Health and Medical Research Council (NHMRC) for financial support towards this research through a project grant (APP1024314). R.A.D. and K.T.A. acknowledge the Australian Research Council (ARC) for an ARC Linkage Grant (LP120200339) and an ARC Future Fellowship, respectively. We also thank the ARC for support toward NMR and MS equipment (Grant LE0668477 and LE0237908). G. MacFarlane (University of Queensland) and W. Loa (Griffith University) are 
acknowledged for HRESIMS measurements. We also acknowledge the Australian Red Cross Blood Service for the provision of human blood and sera.

\section{Author Contributions}

B.D.S. designed and conducted all synthetic experiments and analyzed the results. T.S.S. and K.T.A. designed and performed all the biological experiments, and contributed to data interpretation. M.J.C. assisted with synthetic experimental design, and SAR data analysis. J.M.W. obtained the X-ray diffraction data for compound 11, and solved the crystal structure. R.A.D. was the project leader overseeing the design of the experiments, analysis of the results and the identification and characterization of all compounds. All authors contributed to manuscript preparation.

\section{Conflicts of Interest}

The authors declare no conflict of interest.

\section{References}

1. Davis, R.A.; Duffy, S.; Fletcher, S.; Avery, V.M.; Quinn, R.J. Thiaplakortones A-D: Antimalarial Thiazine Alkaloids from the Australian Marine Sponge Plakortis lita. J. Org. Chem. 2013, 78, 9608-9613.

2. Pouwer, R.H.; Deydier, S.M.; Le, P.V.; Schwartz, B.D.; Franken, N.C.; Davis, R.A.; Coster, M.J.; Charman, S.A.; Edstein, M.D.; Skinner-Adams, T.S.; et al. Total Synthesis of Thiaplakortone A: Derivatives as Metabolically Stable Leads for the Treatment of Malaria. ACS Med. Chem. Lett. 2013, 5, 178-182.

3. Schwartz, B.; Skinner-Adams, T.; Andrews, K.T.; Coster, M.; Edstein, M.; MacKenzie, D.; Charman, S.; Koltun, M.; Blundell, S.; Campbell, A.; et al. Synthesis and antimalarial evaluation of amide and urea derivatives based on the thiaplakortone A natural product scaffold. Org. Biomol. Chem. 2015, 13, 1558-1570.

4. Hollis Showalter, H.D.; Pohlmann, G. An Improved Synthesis of 4,7-Dimethoxy-1H-Indole. Org. Prep. Proc. Int. 1992, 24, 484-488.

5. Jackson, Y.A.; Billimoria, A.D.; Sadanandan, E.V.; Cava, M.P. Regioselective Amination of Indole-4,7-quinones. J. Org. Chem. 1995, 60, 3543-3545.

6. Rajeswari, S.; Drost, K.J.; Cava, M.P. A convenient reductive cyclization of $\beta, 2$-dinitrostyrenes to indoles. Heterocycles 1989, 29, 415.

7. Schmitz, F.J.; Bloor, S.J. Xesto- and halenaquinone derivatives from a sponge, Adocia sp., from Truk lagoon. J. Org. Chem. 1988, 53, 3922-3925.

8. Cherif, M.; Cotelle, P.; Catteau, J.P. General synthesis of 2,3-substituted 5-membered heterocyclic quinones. Heterocycles 1992, 34, 1749-1758.

9. Kitahara, Y.; Nakahara, S.; Numata, R.; Kubo, A. Synthesis of 4,7-Indolequinones. The Oxidative Demethylation of 4,7-Dimethoxyindoles with Ceric Ammonium Nitrate. Chem. Pharm. Bull. 1985, $33,2122-2128$. 
10. Lipinski, C.A.; Lombardo, F.; Dominy, B.W.; Feeney, P.J. Experimental and computational approaches to estimate solubility and permeability in drug discovery and development settings. Adv. Drug Deliv. Rev. 2001, 46, 3-26.

11. Still, W.C.; Kahn, M.; Mitra, A. Rapid chromatographic technique for preparative separations with moderate resolution. J. Org. Chem. 1978, 43, 2923-2925.

12. Pangborn, A.B.; Giardello, M.A.; Grubbs, R.H.; Rosen, R.K.; Timmers, F.J. Safe and Convenient Procedure for Solvent Purification. Organometallics 1996, 15, 1518-1520.

13. Sheldrick, G.M. A short history of SHELX. Acta Cryst. 2008, A64, 112-122.

14. Farrugia, L.J. ORTEP-3 for windows-A version of ORTEP-III with a graphical user interface (GUI). J. Appl. Cryst. 1997, 30, 565.

15. Farrugia, L.J. WinGX suite for small-molecule single-crystal crystallography. J. Appl. Cryst. 1999, 32, 837-838.

16. Skinner, T.S.; Manning, L.S.; Johnston, W.A.; Davis, T.M. E. In vitro stage-specific sensitivity of Plasmodium falciparum to quinine and artemisinin drugs. Int. J. Parasitol. 1996, 26, 519-525.

17. Huber, W.; Koella, J.C. A comparison of three methods of estimating $\mathrm{EC}_{50}$ in studies of drug resistance of malaria parasites. Acta Trop. 1993, 55, 257-261.

(C) 2015 by the authors; licensee MDPI, Basel, Switzerland. This article is an open access article distributed under the terms and conditions of the Creative Commons Attribution license (http://creativecommons.org/licenses/by/4.0/). 